\title{
JOHN MANN GOGGIN, 1916-1963
}

\author{
IRVING Rouse
}

\section{$\mathrm{T}$} HE DEATH of John M. Goggin on May 4, 1963, cut short a highly productive career in American archaeology. Into the 47 years of his life Goggin crowded more activity, both professional and personal, than most of us experience in a full lifetime, and achieved more than most. He was born in Chicago, on May 27, 1916, but grew up in Miami, Florida, where his father, a dentist, had set up practice. His father introduced him to the Everglades, and he roamed them as a boy, acquiring an interest in natural history and anthropology that was to shape his adult life. While still a high school student in Miami, he had already located a number of archaeological sites and was making significant collections. He began college at the University of Florida but, since it had little to offer in the subjects that interested him, moved on to the University of New Mexico where he received a B.A. in anthropology in 1938. He continued at New Mexico for several years, doing part-time graduate work, and in 1941-42 served as curator of the Coronado State Monument. With the outbreak of war, from which he was kept by physical disability, he returned to Florida and worked as an engineer in the construction of airports.

After the war an offer of an assistantship in the Yale Peabody Museum made it possible for him to do graduate work in anthropology. $\mathrm{He}$ received an M.A. from Yale in 1946 and a Ph.D. in 1948. Then he returned to the University of Florida as Associate Professor of Anthropology and remained there the rest of his life. He was promoted to full Professor and made Acting Head of a new Department of Anthropology in 1961, and became Research Professor of Anthropology in 1963, when the ravages of cancer made it impossible for him to continue his teaching and administrative duties.

Development of anthropology at the University of Florida must be rated as one of Goggin's major achievements. He was the first person in our profession to teach there, as a member of the Sociology Department, and through his energy, enthusiasm, and ability to attract students gradually built up support, first for a joint Department of Sociology and Anthropology and finally for a separate Department of Anthropology. By the time of his death, this depart- ment had acquired one of the largest staffs in the Southeast, had granted a number of M.A.'s in anthropology, and was sending a succession of students to other universities for doctoral work.

Goggin was also instrumental in forming the Florida Anthropological Society and served as Editor of its journal from 1949 to 1951. He was Assistant Editor of American Antiquity from 1950 to 1954. In 1951, the Junta Nacional de Arqueología y Etnología in Cuba made him its first foreign member. He was also active in the Florida Academy of Sciences and the Florida Historical Society, and rarely missed a meeting of either the Society for American Archaeology or the Southeastern Archaeological Conference.

He never lost the love of the field that he had acquired in his youth and was most successful in imparting it to his students. It was his good fortune to be able to return to the scene of his boyhood studies and to build upon them. Throughout his life he continued to accumulate information on the archaeology of the Glades area, putting it into a huge manuscript, as yet unpublished, which may be unequalled in its coverage of a single archaeological area, reflecting as it does not only Goggin's field studies but also his thorough knowledge of the ecology, ethnohistory, and ethnology of the area. $\mathrm{He}$ has published a somewhat less detailed monograph on the archaeology of the Lower St. Johns area (1952d), which contains a part of the results of a state-wide archaeological survey he organized in connection with his student-training program. For the state as a whole, this survey includes over 3000 sites, in more than 50 of which he did some digging.

Surveying was more attractive to him than excavation and he rarely dug intensively. Indeed, he has published only a single monographic site report, on the excavations he and Frank H. Sommer III undertook on Upper Matecumbe Key, Florida, while both were graduate students at Yale (1949c). He was basically a collector, not only of sites and specimens including shells and other natural objects as well as artifacts - but also of books, coins, stamps, and art objects. In his studies he paid more attention to museum materials than do most ar- 


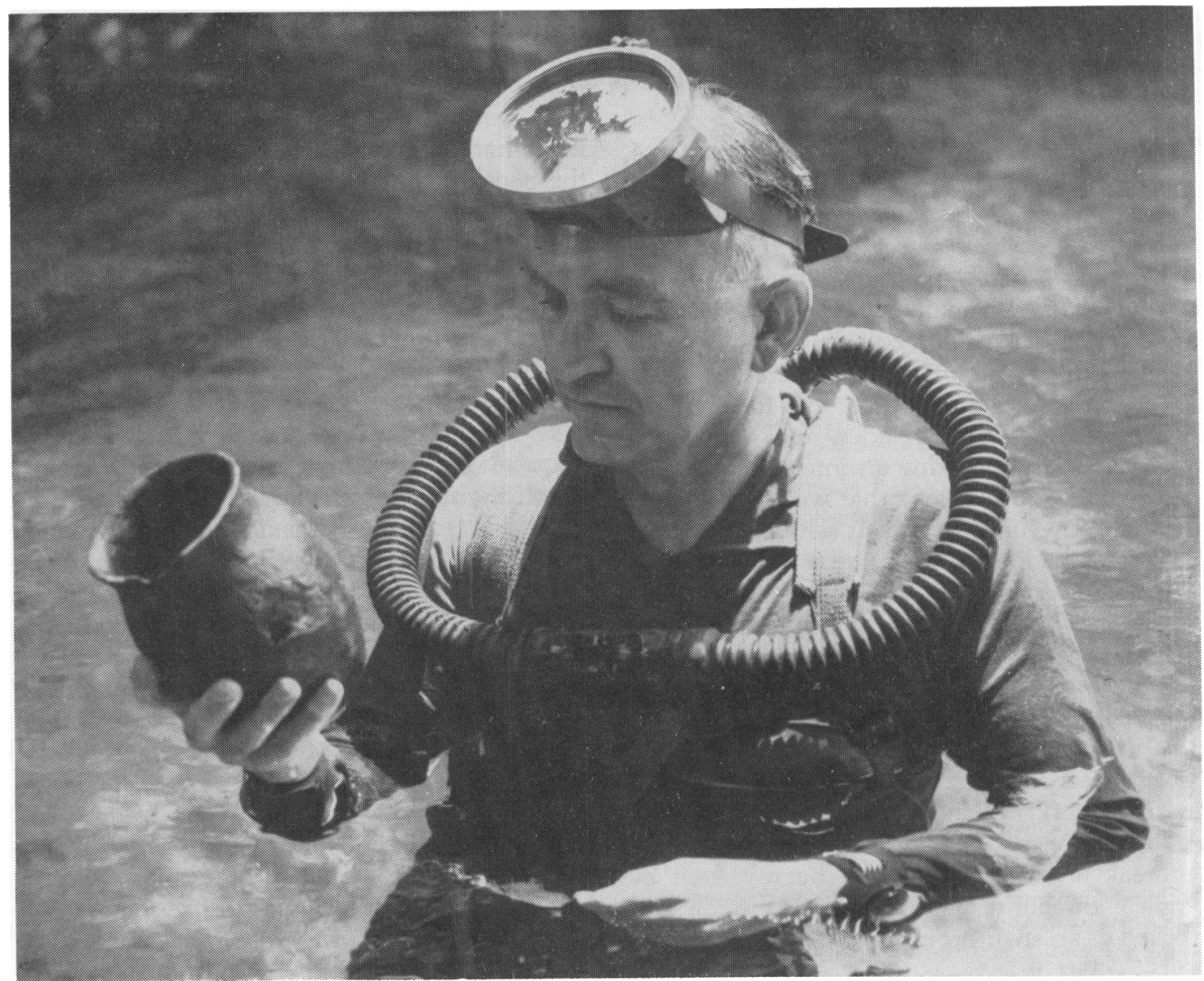

JoHN M. GoGgIN

chaeologists, and he built up an excellent series of type collections for the use of his students at the University of Florida.

As a collector he was unusually sensitive to the problems of sampling. In his first archaeological paper, written while still an undergraduate student at the University of New Mexico (1939c), he established a chronology by comparing the potsherds he had collected from the opposite ends of a Glades midden. Subsequently, at the Goodland Point midden, he marked off 16 distinct parts of the surface, collected separately from each of them, seriated the collections to establish a sequence of five periods, and used the sequence to work out a theory of midden building for South Florida. He referred to this as a method of "controlled sample collecting" (1950a: 65).

While still a graduate student at Yale, he published in this journal a paper on the archaeological areas and periods in Florida, which is still the basic chronological formulation for the state (1947c). He elaborated upon this in his doctoral dissertation, covering the spare framework of areas and periods with solid wood in the form of "cultural patterns" and offering an ecological interpretation of these patterns, in accordance with another of his boyhood interests. It was characteristic of him to include the historic as well as prehistoric patterns and to approach the historic patterns from the standpoint of ethnohistory and ethnology as well as archaeology.

The section of the dissertation dealing with the Lower St. Johns area was subsequently expanded and published as a monograph, to which reference has already been made (1952d). The discussion of the prehistoric patterns - renamed "traditions" at the writer's suggestion - was published as an article in the symposium The Florida Indian and his Neighbors (1949b). It drew the following comments from Gordon $\mathrm{R}$. 
Willey and Philip Phillips, in Method and Theory in American Archaeology (Chicago, 1958: 36-7): "The first significant use of the tradition concept in eastern North American studies, so far as the authors are aware, was by John Goggin . . . It seems to us that ... he has discovered the outstanding merit of the tradition as a methodological tool, namely, its flexibility. Goggin also, rather more than others who have used the concept, emphasizes the importance of environmental factors in the shaping and conserving of traditions."

A new field technique, underwater archaeology, was under development at the time Goggin joined the faculty of the University of Florida, and he was quick to see that this technique would be especially useful in Florida, with its many lakes, streams, and springs. Enlisting the support of the Wenner-Gren Foundation and of his university administration, he was able to acquire a complete set of diving equipment, including aqualungs and a barge with a suction dredge, and located a series of underwater sites which ranged in age from late Pleistocene to the Seminole occupation of Florida. His recovery of Seminole remains was of greatest value since it filled a gap in the dry-land archaeology. He prided himself on his ability to out-dive his students, as well as the colleagues who came to visit him, and was pleased to receive in 1959 a "Pat on the Back" from Sports Illustrated for his underwater activity. Unfortunately, he died before he could complete his research and did not have an opportunity to publish on it, except for a definitive paper on the nature and limitations of underwater archaeology, which appeared in this journal (1960c).

Goggin's preoccupation with Florida caused him to be typed by many people as a local archaeologist. This bothered him, and with good reason. As has been noted, he made a number of contributions in method and theory which have general significance. Moreover, he seized every opportunity to follow up leads outside the state and beyond the field of archaeology. During his years in New Mexico, for example, he became interested in Southwestern ethnology and devoted five of his first seven papers to it. He studied Seminole and other Indian colonies in Louisiana, Oklahoma, the Bahamas, and Mexico (1946b, 1951d), and he was active in Seminole claims litigation (1963a). Wherever he went he collected ethnological specimens, and these served as the basis for a number of articles, for example, on style areas among the Southeastern Indians (1952g). His course on the American Indian was one of his favorites, and he had hoped to write a textbook for it.

But it was Latin America which most attracted him and which eventually came to compete with Florida for his attention. While a student at New Mexico, he came under the influence of Donald D. Brand, then Chairman of the Department of Anthropology at that university, and through him came to participate in three summer field trips to Mexico in 1936, 1939, and 1941. Between these, in 1937, he spent a summer on Andros Island in the Bahamas. His first two articles in American Antiquity were a result; they reported on site surveys of Andros Island and of the Río Tepalcatepec Basin, Michoacán, Mexico (1939b, 1943).

A person with his interest in historic archaeology could hardly have avoided moving into Latin America, since Florida was a part of it during so much of the colonial period. He began to study the Spanish pottery he found in the Indian mission sites of Florida, especially the form known as majolica, and was able to classify majolica potsherds into types, following the standard procedure for dealing with Southwestern and Southeastern Indian pottery. He proceeded to date the types through their occurrence at sites mentioned in the historic sources and was then able to use these types to determine the ages of undocumented sites. In this research he worked not only with his own excavated materials from Florida but also with museum collections from the Southwest and from Mexico (1950e). The result was a detailed chronology for the 17th century, expressed in terms of Spanish pottery.

To carry this chronology back into the 15th and 16th centuries, Goggin next undertook excavations in the original Spanish settlements on Hispaniola and in the towns subsequently established on Cuba, Jamaica, and in the state of Puebla, Mexico. Here, he collaborated closely with the local archaeologists, such as Emile de Boyrie Moya on the island of Hispaniola in the Dominican Republic, and Oswaldo Morales Patiño in Cuba. He was able to seriate his majolica types, not only in terms of surface collections but also on the basis of stratigraphic tests in Santo Domingo and Puebla, and was proud of the fact that the seriations are consistent with the documentary references to the 
sites, since this demonstrates the validity of the approach.

Goggin prepared a large monograph on his majolica research, which Tulane University agreed to issue as a Publication of its Middle American Research Institute, but could never bring himself to send it to the editor because he kept adding new material. For example, during the summer of 1953 he was invited by the writer to carry on joint excavations in Trinidad, at the southern end of the Antilles. The writer had discovered the existence of a series of 16 thand 17 th-century Indian missions on Trinidad, he wanted to add the Indian pottery of these missions to his chronology of the prehistoric pottery of the island, and he needed Goggin's help in identifying the site of the missions by means of their Spanish pottery. Goggin, in turn, was able to obtain additional data for the majolica monograph. We planned a joint publication on Trinidad archaeology, but it remained unfinished at the time of Goggin's death. (A preliminary report has been issued as an appendix to J. A. Bullbrook, On the Excavation of a Shell Mound at Palo Seco, Trinidad, British West Indies, Yale University Publications in Anthropology, No. 50, pp. 94-114, New Haven, 1953.)

During the winter of 1953, Goggin joined J. M. Cruxent of Venezuela in excavations at the site of Nueva Cadiz on Cubagua Island, the first Spanish settlement in South America, again in order to collect more data for the majolica report. This excavation had an unexpected consequence; Cruxent and Goggin found a pot full of pearls in the floor of a house ruin and, although the pearls were too eaten away to have any commercial value, they aroused such local interest that Cruxent was able to obtain money from various sources within the Venezuelan government for six years of continuous digging; this made Nueva Cadiz probably the most thoroughly studied of all early colonial sites in Latin America (Rouse and Cruxent, Venezuelan Archaeology, New Haven, 1963, Chapter 9).

The process of accumulating additional data for the majolica volume went on right up to Goggin's death. Last January, during a respite in his final illness, he visited Panama and dug an early colonial kiln in that country. He also made plans to go to East Africa to investigate medieval Arab sites, where he had heard that majolica is abundant, but his death prevented this.
Another form of Spanish pottery to which Goggin devoted much attention was the olive jar. He contributed a paper on this subject to a Caribbean volume of the Yale University Publications in Anthropology (1960b), in which he went beyond the concept of type, with which he had been concerned in his majolica study, to work with the concept of mode, which he found to be a more sensitive indicator of time, so far as olive jars are concerned.

$\mathrm{He}$ intended to apply the methods he was developing for the study of Spanish pottery to other types of historic artifacts, and by the time of his death he had written another as yet unpublished paper on European beadwork. In conversation, he stressed the value of a combination of approaches: not only surface collecting, stratigraphic tests, typology, and seriation - especially in sites tightly datable through historic documents - but also studies of similar artifacts in art museums, examination of dated works of art (such as Velazquez' still lifes and portraits), and archival investigations of such sources as the cargo lists of the Spanish fleets. The ultimate result would have been to provide several series of securely dated types of European goods for use in determining the age of both Indian and non-Indian sites, as well as increased understanding of the economics and other aspects of culture contact between the Indians and Europeans.

Interest in the Caribbean increased markedly at the University of Florida while Goggin was on the faculty there, and he contributed to it in a number of ways, helping the university library to accumulate books on the area, giving artifacts to the Florida State Museum, and encouraging his students to do research in the West Indies. He was instrumental in arranging for a number of specialists in Caribbean archaeology to speak at the university's annual conference on that area. He himself gave a paper on the archaeology of Central America (1961a), which is perhaps the best synthesis of that area yet published.

Shortly before his death, Goggin was invited by his friend Emile de Boyrie Moya to collaborate in a program of archaeological research in the Dominican Republic under the joint sponsorship of the Universities of Florida and Santo Domingo. The effect would have been to carry his Dominican research back from the colonial period, which he had already studied intensively, into prehistory. It is most unfortunate that 
he was unable to carry through this program, since Dominican archaeology has lagged behind that of the rest of the Greater Antilles. Had Goggin lived, he would very likely have devoted more and more attention to the Caribbean area and have emerged as one of its leading authorities.

Goggin appeared to have few doubts about his own research; it concerned him more that other people were doing theirs improperly. Yet he was not inflexible. He came to Yale determined to resist the writer's "radical" ideas but gradually adopted those which suited his interests and gave as much in return. He was a man of strong likes and dislikes, which sometimes reduced his effectiveness, but rarely acted from prejudice and was a good friend to those who knew him well. It is a measure of his success in personal relationships that, upon learning of his final illness, his friends banded together to publish a volume of his writings (1963c). The following bibliography is taken from this volume.

\section{7}

a) Calendar of Eastern Pueblo Festivals, September to December. New Mexico Anthropologist, Vol. 2, No. 1, pp. 21-3. Albuquerque. (Reprinted in 1963c.)

b) The Present Condition of the Florida Seminoles. New Mexico Anthropologist, Vol. 1, No. 3, pp. 37-9. Albuquerque.

c) Tarahumara Belt Weaving and Design. New Mexico Anthropologist, Vol. 1, No. 6, pp. 87-90. Albuquerque.

1938

Calendar of Eastern Pueblo Festivals. New Mexico Anthropologist, Vol. 2, Nos. 4-5, pp. 89-94. Albuquerque. (Reprinted in 1963c.)

\section{9}

a) Additional Pueblo Ceremonies, 1939. New Mexico Anthropologist, Vol. 3, Nos. 3-4, pp. 62-3. Albuquerque.

b) An Anthropological Reconnaissance of Andros Island, Bahamas. American Antiquity, Vol. 5, No. 1, pp. 21-6. Menasha.

c) A Ceramic Sequence in South Florida. New Mexico Anthropologist, Vol. 3, Nos. 3-4, pp. 35-40. Albuquerque. (Reprinted in 1963c.)

d) Louisiana Choctaw Basketry. El Palacio, Vol. 46, No. 6, pp. 121-3. Santa Fe.

e) A Note on Cheyenne Peyote. New Mexico Anthropologist, Vol. 3, No. 2, pp. 26-30. Albuquerque. (Reprinted in 1963c.)

f) Notes on Some 1938-1939 Pueblo Dances. New Mexico Anthropologist, Vol. 3, No. 2, pp. 30-2. Albuquerque.

\section{0}

a) A Ball Game at Santo Domingo. American Anthropologist, Vol. 42, No. 2, pp. 364-6. Menasha. b) The Distribution of Pottery Wares in the Glades Archaeological Area of South Florida. New Mexico Anthropologist, Vol. 4, No. 2, pp. 22-33. Albuquerque.

c) Silver Work of the Florida Seminole. El Palacio, Vol. 47, No. 2, pp. 25-32. Santa Fe.

d) The Tekesta Indians of Southern Florida. Florida Historical Quarterly, Vol. 18, No. 4, pp. 274-84. Tal. lahassee.

1941

Some Problems of the Glades Archeological Area, Florida. Newsletter of the Southeastern Archaeological Conference, Vol. 2, No. 4, pp. 24-6. Baton Rouge.

1942

A Prehistoric Wooden Club from Southern Florida. American Anthropologist, Vol. 44, No. 2, pp. 327-8. Menasha.

1943

An Archaeological Survey of the Rio Tepalcatepec Basin, Michoacán, Mexico. American Antiquity, Vol. 9, No. 1, pp. 44-58. Menasha. (Reprinted in 1963c.)

1944

a) Archeological Investigations on the Upper Florida Keys. Tequesta, No. 4, pp. 13-35. Coral Gables.

b) A Tentative Formulation of Pottery Types for the Glades Area. 11 pp. Mimeographed, New Haven.

\section{5}

a) Review of "Archaeological Investigations in El Salvador," by John M. Longyear III. American Journal of Science, Vol. 243, No. 7, pp. 412-14. New Haven.

b) Review of "Old Oraibi, a Study of the Hopi Indians of the Third Mesa," by Mischa Titiev. American Journal of Science, Vol. 243, No. 2, p. 112. New Haven.

\section{6}

a) Ceramic Stratigraphy at Upper Matecumbe Key, Florida. $51 \mathrm{pp}$. Unpublished master's thesis in the library of the Department of Anthropology, Yale University, New Haven.

b) The Seminole Negroes of Andros Island, Bahamas. Florida Historical Quarterly, Vol. 24, No. 3, pp. 20106. Tallahassee. (Reprinted in 1963c.)

\section{7}

a) An Anthropological Bibliography of the Eastern Seaboard (edited with Irving Rouse). Eastern States Archeological Federation Research Publication, No. 1. Yale Peabody Museum, New Haven.

b) Manifestations of a South Florida Cult in Northwestern Florida. American Antiquity, Vol. 12, No. 4, pp. 273-6. Menasha.

c) A Preliminary Definition of Archaeological Areas and Periods in Florida. American Antiquity, Vol. 13, No. 2, pp. 114-27. Menasha. (Reprinted in 1963c.)

d) Review of "Textiles of Highland Guatemala," by Lila M. O'Neale. American Antiquity, Vol. 12, No. 4, p. 280. Menasha.

\section{8}

a) Culture and Geography in Florida Prehistory. 302 pp. Unpublished doctoral dissertation in the Sterling Memorial Library, Yale University, New Haven.

b) Florida Archeology and Recent Ecological Changes. Journal of the Washington Academy of Sciences, Vol. 38, No. 7, pp. 225-33. Washington. (Reprinted in $1963 \mathrm{c}$.)

c) A New Collier County Map. Florida Historical Quarterly, Vol. 26, No. 4, pp. 353-5. Tallahassee. 
d) Review of "Caves of the Upper Gila and Hueco Areas in New Mexico and Texas," by C. B. Cosgrove. American Journal of Science, Vol. 246, No. 5, pp. 325-6. New Haven.

e) Review of "The Everglades, River of Grass," by Marjory Stoneman Douglas. Journal of American Folklore, Vol. 61, No. 240, pp. 229-30. New York.

f) Review of "Papers of the Michigan Academy of Science, Arts and Letters," Vol. 31 (1945), Part 3, General Section. American Antiquity, Vol. 13, No. 4, p. 336. Menasha.

g) Review of "Prehistoric Indians of the Southwest," by H. M. Wormington. American Journal of Science, Vol. 246, No. 5, pp. 326-7. New Haven.

h) A Revised Temporal Chart of Florida Archeology. Florida Anthropologist, Vol. 1, Nos. 3-4, pp. 57-60. Gainesville.

i) Some Pottery Types from Central Florida. Gainesville Anthropological Association, Bulletin, No. 1, pp. 1-14. Mimeographed, Gainesville.

j) A West Indian Ax from Florida (with Irving Rouse). American Antiquity, Vol. 13, No. 4, pp. 323-5. Menasha.

1949

a) Anthropology at the University of Florida. Southern Indian Studies, Vol. 1, No. 2, p. 64. Chapel Hill.

b) Cultural Traditions in Florida Prehistory. In "The Florida Indian and His Neighbors," edited by John W. Griffin, pp. 13-44. Inter-American Center, Rollins College, Winter Park, Florida. (Reprinted in 1963c.)

c) Excavations on Upper Matecumbe Key, Florida (with Frank H. Sommer III). Yale University Publications in Anthropology, No. 41. 101 pp. New Haven.

d) A Florida Indian Trading Post, Circa 1763-1784. Southern Indian Studies, Vol. 1, No. 2, pp. 35-8. Chapel Hill.

e) An Historic Indian Burial, Alachua County, Florida (with Mary E. Godwin, Earl Hester, David Prange, and Robert Spangenberg). Florida Anthropologist, Vol. 2, Nos. 1-2, pp. 10-25. Gainesville.

f) Plaited Basketry in the New World. Southwestern Journal of Anthropology, Vol. 5, No. 2, pp. 165-8. Albuquerque. (Reprinted in $1963 \mathrm{c}$.)

g) Prehistoric Florida Archeology (Abstract). American Antiquity, Vol. 15, No. 2, p. 175. Menasha.

h) A Southern Cult Specimen from Florida. Florida Anthropologist, Vol. 2, Nos. 1-2, pp. 36-8. Gainesville.

\section{0}

a) Cultural Occupation at Goodland Point, Florida. Florida Anthropologist, Vol. 2, Nos. 3-4, pp. 65-91. Gainesville. (Reprinted in 1963c.)

b) An Early Lithic Complex from Central Florida. American Antiquity, Vol. 16, No. 1, pp. 46-9. Salt Lake City.

c) Florida Archeology - 1950. Florida Anthropologist, Vol. 3, Nos, 1-2, pp. 9-20. Gainesville.

d) The Indians and History of the Matecumbe Region. Tequesta, No. 10, pp. 13-24. Coral Gables. (Reprinted in 1963c.)

e) A Preliminary Consideration of Spanish Introduced Majolica Pottery in Florida and the Southwest. 29 pp. Mimeographed, University of Florida, Gainesville.

f) Review of "Archeology of the Florida Gulf Coast," by Gordon R. Willey. Florida Historical Quarterly, Vol. 29, No. 1, pp. 53-7. Tallahassee. g) The State-wide Archeological Site Recording System. Laboratory Notes, Anthropology Laboratory, University of Florida, No. 1. 4 pp. Gainesville.

h) Stratigraphic Tests in the Everglades National Park. American Antiquity, Vol. 15, No. 3, pp. 228-46. Menasha.

\section{1}

a) Beaded Shoulder Pouches of the Florida Seminole. Florida Anthropologist, Vol. 4, Nos. 1-2, pp. 2-17. Gainesville. (Reprinted in 1963c.)

b) Fort Pupo: A Spanish Frontier Outpost. Florida Historical Quarterly, Vol. 30, No. 2, pp. 139-92. Tallahassee.

c) Florida's Indians. Economic Leaflets, Vol. 10, No. 8. 4 pp. College of Business Administration, University of Florida, Gainesville.

d) The Mexican Kickapoo Indians. Southwestern Journal of Anthropology, Vol. 7, No. 3, pp. 314-27. Albuquerque. (Reprinted in 1963c.)

e) The Snapper Creek Site. Florida Anthropologist, Vol. 3, Nos. 3-4, pp. 50-64. Gainesville. (Reprinted in 1963c.)

f) Review of "Bibliographic Organization," by Jesse $H$. Shera and Margaret E. Egan. American Anthropologist, Vol. 53, No. 4, p. 579. Menasha.

g) Review of "Bird's Eye View of the Pueblos," by Stanley A. Stubbs. American Scientist, Vol. 39, No. 2, p. 326. New Haven.

h) Review of "Here They Once Stood," by Mark F. Boyd, Hale G. Smith, and John W. Griffin. Florida Anthropologist, Vol. 3, Nos. 3-4, pp. 65-6. Gainesville.

i) Review of "Hopi Katchina Dolls," by Harold S. Colton. American Scientist, Vol. 39, No. 2, pp. 326-7. New Haven.

\section{2}

a) Archeological Notes on Lower Fisheating Creek. Florida Anthropologist, Vol. 4, Nos. 3-4, pp. 50-66. Gainesville.

b) Archeological Sites in the Everglades National Park. Laboratory Notes, Anthropology Laboratory, Univer. sity of Florida, No. 2. 10 pp. Gainesville.

c) The First Floridians. In "The Florida Handbook," compiled by Allen Morris, pp. 343-8. Tallahassee.

d) Space and Time Perspective in Northern St. Johns Archeology, Florida. Yale University Publications in Anthropology, No. 47. 147 pp. New Haven.

e) Review of "Cherokee Dance and Drama," by Frank G. Speck and Leonard Broom in collaboration with Will West Long. American Anthropologist, Vol. 54, No. 1, p. 102. Menasha.

f) Review of "A Survey of Indian River Archeology, Florida," by Irving Rouse and "Chronology at South Indian Field, Florida," by Vera Masius Ferguson. Florida Anthropologist, Vol. 4, Nos. 3-4, pp. 77-9. Gainesville.

g) Style Areas in Historic Southeastern Art. In "Indian Tribes of Aboriginal America," edited by Sol Tax, Proceedings of the 29th International Congress of Americanists, Vol. 3, pp. 172-6. University of Chicago Press, Chicago. (Reprinted in 1963c.)

\section{3}

a) An Introductory Outline of Timucua Archeology. Newsletter of the Southeastern Archaeological Conference, Vol. 3, No. 3, pp. 4-15, 17. Baton Rouge.

b) Review of "Benjamin Hawkins, Indian Agent," by Merritt B. Pound. Florida Historical Quarterly, Vol. 31, No. 4, pp. 309-10. Tallahassee. 
c) Review of "Prehistoric Florida: A Review," by John W. Griffin. American Antiquity, Vol. 19, No. 2, pp. 188-9. Salt Lake City.

d) Seminole Archeology in East Florida (Abstract). Newsletter of the Southeastern Archaeological Conference, Vol. 3, No. 3, pp. 16, 19. Baton Rouge.

e) Spanish Pottery in Florida Archeology (Abstract). Eastern States Archeological Federation, Bulletin, No. 11, p. 7. Trenton, N.J.

a) Are There De Soto Relics in Florida? Florida Historical Quarterly, Vol. 32, No. 3, pp. 151-62. Tallahassee.

b) The First Floridians. In "The Florida Handbook," compiled by Allen Morris, 4th edition, pp. 13-20. Tallahassee.

c) Historic Metal Plummet Pendants. Florida Anthropologist, Vol. 7, No. 1, p. 27. Gainesville.

\section{5}

a) Archeological Excavations in the Courtyard of Castillo de San Marcos, St. Augustine, Florida (with J. C. Harrington and Albert C. Manucy). Florida Historical Quarterly, Vol. 34, No. 2, pp. 99-141. Tallahassee. (Reprinted as St. Augustine Historical Society, Bulletin 1, 1956.)

b) Osceola: Portraits, Features, and Dress. Florida Historical Quarterly, Vol. 33, Nos. 3-4, pp. 161-92, 6 pls. Tallahassee. (Reprinted in "The Complete Story of Osceola," St. Augustine Historical Society, 1955.)

c) Review of "Indians of the Southern Colonial Frontier, the Edmond Atkin Report, and Plan of 1755," edited by Wilbur R. Jacobs. American Anthropologist, Vol. 57, No. 5, p. 1069. Menasha.

d) Review of "On the Excavation of a Shell Mound at Palo Seco, Trinidad, B.W.I.," by J. A. Bullbrook. American Anthropologist, Vol. 57, pp. 648-9. Menasha.

e) Review of "On the Excavation of a Shell Mound at Palo Seco, Trinidad, B.W.I.", by J. A. Bullbrook. American Journal of Archeology, Vol. 59, No. 2, pp. 197-8. Menasha.

\section{6}

a) The Long Nosed God Mask in Eastern United States (with Stephen Williams). Missouri Archeologist, Vol. 18, No. 3, pp. 3-72. Columbia.

b) Review of "The Jaketown Site in West-Central Mississippi," by James A. Ford, Philip Phillips, and William G. Haag. American Antiquity, Vol. 21, No. 4, pp. 431-2. Salt Lake City.

\section{7}

a) Review of "Seminole Music," by Francis Densmore. American Anthropologist, Vol. 59, No. 6, pp. 1098-9. Menasha.

b) Zamia Starch in Santo Domingo; a Contribution to the Ethnobotany of the Dominican Republic (with Emile de Boyrie Moya and Marguerita K. Krestensen). Florida Anthropologist, Vol. 10, Nos. 3-4, pp. 17-40. Gainesville.

\section{8}

a) Absolute Chronology in the Caribbean Area (with Irving Rouse and José M. Cruxent). Proceedings of the 32nd International Congress of Americanists, pp. 508-15. Munksgaard, Copenhagen.

b) Seminole Pottery. In "Prehistoric Pottery of the Eastern United States." 37 pp. Museum of Anthropology, University of Michigan, Ann Arbor. (Reprinted in 1963c.)

\section{9}

a) Review of "A History of Technology," Vols. I and II, edited by Charles Singer et al. American Antiquity, Vol. 25, No. 1, pp. 130-2. Salt Lake City.

b) Review of "Sun Circles and Human Hands: The Southeastern Indians Art and Industries," edited by Emma Lila Fundaburk and Mary Douglass Fundaburk Foreman. Florida Historical Quarterly, Vol. 38 , No. 1, pp. 74-5. Jacksonville.

c) Source Materials for the Study of the Florida Seminole Indians. Laboratory Notes, Anthropology Labora tory, University of Florida, No. 3. 19 pp. Gainesville.

\section{0}

a) Review of "Southeastern Indians, Life Portraits: a Catalogue of Pictures, 1564-1860," edited by Emma Lila Fundaburk. American Antiquity, Vol. 25, No. 3, p. 431. Salt Lake City.

b) The Spanish Olive Jar, an Introductory Study. Yale University Publications in Anthropology, No. 62. 37 pp. New Haven. (Reprinted in 1963c.)

c) Underwater Archaeology: Its Nature and Limitations. American Antiquity, Vol. 25, No. 3, pp. 348-54. Salt Lake City. (Reprinted in 1963c.)

\section{1}

a) Central America, the Unturned Key to New World Archeology. In "The Caribbean - the Central American Area," edited by A. Curtis Wilgus, pp. 18-27. Gainesville.

b) Comment on John Witthoft's "Eastern Woodlands Community Typology and Acculturation." In "Symposium on Cherokee and Iroquois Culture," edited by William N. Fenton and John Gulick, pp. 77-81. Bureau of American Ethnology, Bulletin 180. Washington.

1962

a) Recent Developments in Underwater Archeology. Newsletter of the Southeastern Archeological Conference, Vol. 8, pp. 77-88. Cambridge, Mass.

b) Review of "Ships, Shoals and Amphoras, the Story of Underwater Archeology," by Suzanne de Borhegyi. American Antiquity, Vol. 28, No. 1, p. 108. Salt Lake City.

c) Weeden Island Punctated and Papys Bayou Punctated. Newsletter of the Southeastern Archeological Conference, Vol. 8, pp. 19-23. Cambridge, Mass.

\section{3}

a) The Calusa, a Stratified, Non-Agricultural Society (with Notes on Sibling Marriage) (with William C. Sturtevant). In "Explorations in Cultural Anthropology: Essays Presented to George Peter Murdock," edited by Ward $\mathrm{H}$. Goodenough. In press. McGrawHill, New York.

b) Dr. John M. Goggin - Summary of Testimony. In 'Defendants' Requested Findings of Fact, Objections to Petitioners' Proposed Findings, and Brief," before the Indian Claims Commission, Seminole Indians $v$. United States, Docket Nos. 73 and 151, Appendix, pp. 139-53. U.S. Department of Justice, Washington.

c) Indian and Spanish: Selected Writings (edited by Charles H. Fairbanks, Irving Rouse, and William C. Sturtevant). In press. University of Miami, Coral Gables.

YALE UNIVERSTTY

New Haven, Connecticut July, 1963 